\section{LOUÇA REGIONAL LOUÇA DE MESA?}

A louça do artesanato português conta com o apreço seguro do estrangeiro e constitui por isso uma possibilidade de exportação com interesse. A utilização da cerâmica regional como louça de mesa está no entanto condicionada à necessidade de se satisfazerem normas internacionais no que toca a alguns elementos tóxicos e em particular ao chumbo para o qual os limites de tolerância são muito baixos.

Acontece que quase todos os oleiros empregam o zarcão no vidrado das cerâmicas que fabricam pelo que, tendo encontrado artesãos que o não utilizam, a ENATUR decidiu mandar analisar as respectivas louças. Os teores em chumbo observados foram contudo muito superiores aos limites permissíveis. Dado o interesse que este problema suscita - quer pelas suas consequências a nível de exportação, quer pelos eventuais inconvenientes para a saúde que a utilização sistemática da referida louça possa causar na população - foi apresentado, pela ENATUR, à Universidade de Évora onde foi objecto de análise no respectivo Departamento de Química.

Pôs-se em primeiro lugar a questão de se saber qual a proveniência do chumbo encontrado nos extratos acéticos da referida louça, embora pela tradição do uso de alvaiades de chumbo no fabrico de pigmentos para a decoração de louças pudessemos à partida pensar que aí residisse a sua origem.

As análises dos extratos acéticos (N.P. 1031/1974) da louça sem vidrado e simplesmente vidrada mostraram que em ambos os casos os teores em chumbo eram baixos ( " $1 \mathrm{mg} \mathrm{Pb} / 1)$. Quanto à louça pintada, encontraram-se teores em chumbo muito elevados (compreendidos entre
M. Manuela Mota Batista

e M. Lurdes Pimenta da Silva

Departamento de Química

Universidade de Évora
20 e $700 \mathrm{mg} \mathrm{Pb} / 1)$ que excedem largamente $7 \mathrm{mg} / 1$ que constitui o teor máximo admissivel (Especificação do INII n. $\left.{ }^{\circ} 6 / 1971\right)$.

Foram então feitas análises complementares a diferentes pigmentos utilizados por um dos oleiros e obtiveram-se os seguintes teores em chumbo nos respectivos extratos acéticos:

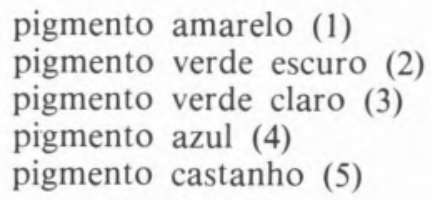

Os resultados conduzem obviamente a recomendar que neste caso particular não sejam utilizados os pigmentos (1), (2) e (4) na decoração da louça. Os mesmos sugerem que, de uma maneira geral, os oleiros interessados na comercialização da sua louça decorativa como louça de mesa procurem obter uma informação prévia quanto ao comportamento dos pigmentos que pensam vir a utilizar face a agentes extractantes que simulem a acção dos alimentos.

O Departamento de Química da Universidade de Évora agradece ao Laboratório Nacional de Engenharia e Tecnologia Industrial e ao Centro de Química Estrutural do Instituto Superior Técnico a colaboração prestada na análise deste problema. 